\title{
A Study of Techno-Pedagogical Skills and Teachers' Performance in HTTTC Kumba, Cameroon
}

\author{
Ngemunang A. N. Lyonga, Gracemary E. Moluayonge, and Asobo J. Nkeng
}

\begin{abstract}
This study set out to investigate the relationship between techno-pedagogic skills and teachers' performance in HTTTC Kumba. It was hypothesized that Technopedagogical skills have no significant relationship with teachers' performance in Higher Technical Teachers' Training College Kumba. A multistaged sampling technique was used for the study and all the fourteen departments in HTTTC Kumba were included in the study. A total of 42 teachers were selected using a simple random sampling technique. The instrument used for the study was a questionnaire. The data was analysed using frequencies and percentages for descriptive statistics while the Chi-Square Test and Pearson's Coefficients of Correlation were used for testing the hypothesis in SPSS version 21. The results revealed that there is a significant positive relationship between technopedagogical skills and teachers' performance in HTTTC Kumba. Based on the results of the findings, it was concluded that techno-pedagogical skills have a significant positive relationship with teachers' performance in HTTTC Kumba. It was recommended that educational practitioners should know how to weave subject area content, pedagogy and technology effectively in their classroom interaction. Lack of knowledge in the part of teachers regarding technopedagogical skills is a major constraint in blending these aspects.
\end{abstract}

Keywords: techno-pedagogical skills, teacher's performance.
Published Online: January 30, 2021

ISSN: $2736-4534$

DOI : $10.24018 /$ ejedu.2021.2.1.31

\section{N. A. N. Lyonga*}

Higher Technical Teachers' Training

College (HTTTC), Kumba

University of Buea, Cameroon

(e-mail: agie.lyonga@gmail.com)

G. E. Moluayonge

Higher Technical Teachers' Training

College (HTTTC), Kumba

University of Buea, Cameroon

(e-mail: graciacallisse@yahoo.com)

A. J. Nkeng

Higher Technical Teachers' Training

College (HTTTC), Kumba

University of Buea, Cameroon

(e-mail: asnkeng2000@yahoo.com)

\section{INTRODUCTION}

The advent of information and communication technologies (ICT) has changed world orientation in general and education in particular through the methods of teaching/learning, teaching aids, curriculum design and educational administration entirely. Techno-pedagogy is the hybrid method of teaching in which information and communication technology (ICT) resources are utilised in the classroom interaction process [8]. Techno-pedagogical skills are those skills needed to use technology for pedagogical reasons and the competence to integrate technology into teaching. Techno-pedagogical skills include sub-skills such as basic technological skills, technology usage skills for knowledge acquisition and personal development, technology usage skills for planning and preparing lesson plans. Acquiring techno-pedagogical proficiency will make teaching and learning a pleasurable exercise as it would lessen the pressure on the teachers, and enable the students to plunge deeper into the knowledge acquisition process.

\section{A. Statement of the Problem}

Techno-pedagogical skills are supposed to be employed in the teaching process in this generation where learners are increasingly becoming techno-centric yet some teachers are so resistant to change by keeping to their traditional pedagogic practices. Consequently, they make learners fail to see reality in a majority of lessons delivered because they do not fit to the current technology-dominated scenarios. Higher Technical Teachers' College (HTTTC) Kumba being a technical teacher training college requires effective collaboration and follow-up from teachers to students yet observations reveal that a wide majority of teachers are yet to embrace techno-pedagogical tools like zoom or googlehangout to improve their collaboration and student follow-up. This consequently makes those teachers stick to the traditional pedagogical skills which have recently come under serious criticisms due to the changing needs of the generation.

In this technology-dominated age, it is expected that the teacher-student gap should be narrowed through e-learning platforms and media sharing technologies but the case is not best in HTTTC Kumba where some teachers still find it difficult to upload or download files on any platform due to underdeveloped techno-pedagogical skills. Some of them are still of the belief that techno-pedagogical tools are for technology specialists and not everyone's concern. These poor perceptions and challenges towards techno-pedagogical skills have varying consequences on the student-teachers, the College and the community since the training received by the student-teachers may end up being substandard due to poor integration of technology by teachers to facilitate learning. With these challenges, it is necessary to investigate the development of techno-pedagogical skills among teachers in HTTTC Kumba. 


\section{B. Relationship between Techno-Pedagogical Skills and Teachers' Performance}

'Reference [2]' found in a study that teachers feel prepared to use technology because they had previously had access and opportunities to use technology in their classrooms; the availability of technology was influenced by the administration, and the administration thought technology was important because their teachers said it was making a difference (teacher beliefs); this lead to greater access, leading teachers to use it more; ultimately this increased teachers level of preparedness.

These technologies include devices such as smart mobile phones, personal digital assistants, computers, radio, television, network communication devices, satellite system, hardware and software, as well as other different services and applications [8].

Following the relationship between technology and pedagogy, [7] emphasized that teachers must continue to be learners themselves to produce the best teaching methods and introduce technology that works for their classroom and the specific needs of their students. They further explained that what teachers decide to bring into the classroom, must "hook" students and make them excited to learn, thus, the programs, materials, and projects done should be meaningful to the students.

From the different works of these researchers, there is enough evidence to believe that technology and pedagogy are strongly related like two sides of the same coin. Technology as viewed by most authors is the road to effective teaching today. The integration of technology by teachers highly depends on the perceived ease of use and efficacy of the teacher in question. Therefore, acquiring skills in techno pedagogy especially in a school like HTTTC Kumba is inevitable for teachers.

\section{1) Purpose:}

The main objective of this study is to assess the relationship between techno-pedagogical skills and teachers' performance in HTTTC Kumba.

\section{2) Research Question:}

What is the relationship between techno-pedagogical skills and teachers' performance in HTTTC Kumba?

\section{3) Hypothesis}

$H_{0}$ : Techno-pedagogical skills have no significant relationship with teachers' performance in HTTTC Kumba.

$H_{a}$ : Techno-pedagogical skills have a significant relationship with teachers' performance in HTTTC Kumba.

\section{MATERIALS AND METHODS}

In this study, 42 teachers from Higher Technical Teacher's Training College, Kumba in Cameroon were selected and administered the questionnaire to, personally by the researchers. This questionnaire was an adaptation of the questionnaire developed by [6]. The questionnaire was made up of four-point Likert scale items (strongly Agree (SA), Agree (A), Disagree (D) and Strongly Disagree (SD). Where $\mathrm{SA}=4, \mathrm{~A}=3, \mathrm{D}=2$, and $\mathrm{SD}=1$.

The multistaged sampling technique was used to get the sample. Multistaged sampling technique is a process of moving from abroad to a narrow sample using a step by step process [1]. In the first step, total population sampling was used and all the fourteen departments in HTTTC Kumba were included in the study. Total population sampling is a type of purposive sampling. According to [5], purposive sampling, also known as subjective or judgmental sampling is a nonprobability sampling technique that does not need underlying theories or a set number of participants. Simply put, the researcher decides what needs to be known and sets out to find people who can and are willing to provide the information by virtue of knowledge or experience [5]. In the second and final step, the simple random sampling technique, a type probability sampling approach, was used to select three teachers from each department. According to [3] simple random sampling is a technique of selecting a sample from the population in such a way that all the elements in the population of the same size have equal chances of being selected. In this study, the reliability and validity of the instrument was achieved by the fact that the instrument to be adapted was obtained from an already published document. Descriptive and Inferential Statistics was used to analyze the data.

\section{FINDINGS AND DISCUSSION}

Of the 42 respondents in this study, $25(59.5 \%)$ of them were males while $17(40.5 \%)$ of them were females. Their ages ranged from between 25 and 30 and right up to 55 years of age. The majority of the participants $(15 / 35.7 \%)$ were between the ages of 36 to 40 years of age followed closely by $41-45$ years of age $(12 / 28.6 \%)$ while only one $(2.4 \%)$ participant was between the ages of 25-30 and 51-55 respectively. Concerning the academic qualifications, most of the respondents were holders of a doctorate degree $(22 / 52.4 \%)$ while a lesser proportion of them had a master's degree $(14 / 33.3 \%)$ while the rest had DIPET/DIPES II $(6 / 14.3 \%)$. Regarding their academic ranks, most of the respondents were assistant lecturers $(20 / 47.6 \%)$ while a lesser majority of them were Instructors $(12 / 28.6 \%)$. There were also $8(19 \%)$ lecturers and $2(4.8 \%)$ associate professors. For the number of years they have been teaching in HTTTC Kumba, a greater proportion of the respondents (30/71.4\%) have been teaching there between 1 and 5years while a smaller portion of them $(12 / 28.6 \%)$ have been teaching there for 6 to 10 years.

In order to answer the research question which was "what is the relationship between techno-pedagogical skills and teachers' performance in HTTTC Kumba?" with the aim of assessing the relationship between techno-pedagogical skills and teachers performance in HTTTC Kumba, Table 1 showed the results obtained from the responses of the 42 sampled teachers.

Table I revealed that an overwhelming total majority $40(95.2 \%)$ agreed while a minor $2(4.8 \%)$ disagreed to the proposition that "including technology into pedagogy improves learning outcomes for my learners" and this led to the overall decision "agree" for that item. 
TABLE I: TEACHERS' VIEWS ON THE RELATIONSHIP BETWEEN TECHNO-PEDAGOGICAL SKILLS AND THEIR PERFORMANCE

\begin{tabular}{|c|c|c|c|c|}
\hline Variable & Description & Freq. & Percent & Decision \\
\hline \multirow{4}{*}{$\begin{array}{l}\text { Including } \\
\text { technology into } \\
\text { pedagogy improves } \\
\text { learning outcomes } \\
\text { for my learners. }\end{array}$} & Strongly Agree & 14 & 33.3 & \multirow{4}{*}{ Agree } \\
\hline & Agree & 26 & 61.9 & \\
\hline & Disagree & 2 & 4.8 & \\
\hline & TOTAL & 42 & 100.0 & \\
\hline \multirow{4}{*}{$\begin{array}{l}\text { With my techno- } \\
\text { pedagogical skills, I } \\
\text { easily sustain the } \\
\text { attention of my } \\
\text { students in class }\end{array}$} & Strongly Agree & 13 & 31.0 & \multirow{4}{*}{ Agree } \\
\hline & Agree & 25 & 59.5 & \\
\hline & Disagree & 4 & 9.5 & \\
\hline & TOTAL & 42 & 100.0 & \\
\hline \multirow{4}{*}{$\begin{array}{l}\text { Techno- } \\
\text { pedagogical skills } \\
\text { help to improve my } \\
\text { students' } \\
\text { participation in } \\
\text { learning activities. }\end{array}$} & Strongly Agree & 14 & 33.3 & \multirow{4}{*}{ Agree } \\
\hline & Agree & 24 & 57.1 & \\
\hline & Disagree & 4 & 9.5 & \\
\hline & TOTAL & 42 & 42.0 & \\
\hline \multirow{4}{*}{$\begin{array}{l}\text { Techno- } \\
\text { pedagogical skills } \\
\text { improve my } \\
\text { assessment quality. }\end{array}$} & Strongly Agree & 6 & 14.3 & \multirow{4}{*}{ Agree } \\
\hline & Agree & 32 & 76.2 & \\
\hline & Disagree & 4 & 9.5 & \\
\hline & TOTAL & 42 & 42.0 & \\
\hline \multirow{3}{*}{$\begin{array}{l}\text { Techno- } \\
\text { pedagogical skills } \\
\text { increase my career } \\
\text { development. }\end{array}$} & Strongly Agree & 15 & 35.7 & \multirow{3}{*}{ Agree } \\
\hline & Agree & 27 & 64.3 & \\
\hline & TOTAL & 42 & 100.0 & \\
\hline \multirow{3}{*}{$\begin{array}{l}\text { An improvement in } \\
\text { my techno- } \\
\text { pedagogical skills } \\
\text { will improve my } \\
\text { performance as a } \\
\text { teacher. }\end{array}$} & Strongly Agree & 30 & 71.4 & \multirow{3}{*}{ Agree } \\
\hline & Agree & 12 & 28.6 & \\
\hline & TOTAL & 42 & 100.0 & \\
\hline
\end{tabular}

Table I further revealed that a total majority of $38(90.5 \%)$ of the sampled teachers opted for agree options while 4(9.5\%) went for disagree options to the proposition that "with my techno-pedagogical skills, I easily sustain the attention of my students in class". The overwhelming agreement led to the decision "agree" for that item. Concerning the statement "techno-pedagogical skills help to improve my students' participation in learning activities", a total majority of $38(90.5 \%)$ agreed while the rest $4(9.5 \%)$ disagreed and this led to the overall decision "agree" for that item.

Table I also showed that a total majority of $38(90.5 \%)$ agreed while the rest $4(9.5 \%)$ disagreed to the statement that "techno-pedagogical skills improve my assessment quality" leading to the overall decision "agree" for that particular item. For the fifth item in Table 1, all the 42(100.0\%) respondents unanimously agreed to the statement that "technopedagogical skills increase my career development" and this led to the overall decision "agree" for that particular item. When presented the suggestion that "an improvement in my techno-pedagogical skills will improve my performance as a teacher", all the $42(100.0 \%)$ of the respondents agreed and this led to the overall decision "agree" for that item.

The responses from teachers indicate that there is possibly a relationship between techno-pedagogical skills and teachers' performance in which techno-pedagogy skills improves learning outcomes, improves learner participation, sustains learner attention, improves assessment quality and improves carrier development for the teacher.

\section{A. Teachers' Performance}

The dependent variable of this study was teachers' performance and it was assessed using two items for which the results are presented in Table II.

TABLE II: TEACHERS' MEASURE OF THEIR LEVEL OF PERFORMANCE

\begin{tabular}{|c|c|c|c|c|}
\hline Variable & Description & Freq. & Percent & Decision \\
\hline \multirow{5}{*}{$\begin{array}{l}\text { My skills in } \\
\text { using } \\
\text { technology for } \\
\text { teaching and } \\
\text { learning is: }\end{array}$} & Excellent & 4 & 9.5 & \multirow{5}{*}{ Good } \\
\hline & Very Good & 7 & 16.7 & \\
\hline & Good & 12 & 28.6 & \\
\hline & Average & 15 & 35.7 & \\
\hline & Poor & 4 & 9.5 & \\
\hline \multirow{6}{*}{$\begin{array}{l}\text { My use of } \\
\text { techno- } \\
\text { pedagogies } \\
\text { improves my } \\
\text { performance in } \\
\text { teaching }\end{array}$} & TOTAL & 42 & 100.0 & \multirow{6}{*}{ Agree } \\
\hline & Strongly Agree & 14 & 33.3 & \\
\hline & Agree & 23 & 54.8 & \\
\hline & Disagree & 2 & 4.8 & \\
\hline & Strongly Disagree & 3 & 7.1 & \\
\hline & TOTAL & 42 & 100.0 & \\
\hline
\end{tabular}

Table II revealed that out of the 42 teachers sampled in HTTTC Kumba, the majority 15(35.7\%) had average skills in techno-pedagogy; $12(28.6 \%)$ are good in using technopedagogy; $7(16.7 \%)$ are very good in techno-pedagogy; $4(9.5 \%)$ are excellent while the rest $4(9.5 \%)$ are poor in the use of techno-pedagogical tools. This led to the overall rate of the pedagogic skills of teachers in HTTTC Kumba is "good".

Table II further revealed that a total majority of 37(88.1\%) of the respondents agreed while $5(11.9 \%$ ) disagreed to the statement that "my use of techno-pedagogies improves my performance in teaching" and this led to the decision "agree" for that statement.

\section{B. Verification of Hypothesis}

$H_{l}$ : Techno-pedagogical skills have no significant relationship with teachers' performance in HTTTC Kumba.

$H_{0}$ : Techno-pedagogical skills have a significant relationship with teachers' performance in HTTTC Kumba.

TABLE III: CORRELATION OF TECHNO-PEDAGOGICAL SKILLS AND TEACHERS' PERFORMANCE

\begin{tabular}{llrrrr}
\hline \multicolumn{6}{c}{ AND TEACHERS' PERFORMANCE } \\
\hline & Value & $\begin{array}{c}\text { Asymp. } \\
\text { Std. Error }\end{array}$ & Approx. $^{\mathrm{b}}$ & $\begin{array}{c}\text { Approx. } \\
\text { Sig. }\end{array}$ \\
\hline $\begin{array}{l}\text { Interval by } \\
\text { Interval }\end{array}$ & Pearson's R & .090 & .071 & .574 & $.039^{\mathrm{c}}$ \\
$\begin{array}{l}\text { Ordinal by } \\
\text { Ordinal }\end{array}$ & $\begin{array}{l}\text { Spearman } \\
\text { Correlation }\end{array}$ & .010 & .162 & .060 & $.042^{\mathrm{c}}$ \\
$\mathrm{N}$ of Valid Cases & 42 & & & \\
\hline
\end{tabular}

a. Not assuming the null hypothesis.

b. Using the asymptotic standard error assuming the null hypothesis.

c. Based on normal approximation.

Table III shows Pearson's moment coefficient of correlation $(\mathrm{R})$ for hypothesis three. With $\mathrm{R}=.090$ and $\mathrm{p}$ value $=.039$; it indicates a weak positive relationship between the independent (Techno-pedagogical skills) and dependent (Teachers' Performance) variables of this hypothesis since .090 is far less than 1 . The p-value $=.039$ is also less than 
$\alpha=0.05$ meaning the relationship is statistically significant. It can then be concluded that there is a weak significant positive relationship between Techno-pedagogical skills and teachers' performance in HTTTC Kumba.

The researcher sought to assess the relationship between techno-pedagogical skills and teachers' performance in HTTTC Kumba. The responses from teachers indicate that there is possibly a relationship between techno-pedagogical skills and teachers' performance in which techno-pedagogy skills improves learning outcomes, improves learner participation, sustains learner attention, improves assessment quality and improves carrier development for the teacher. 'Reference [10]' also supported the results when they found out that computers, projection devices, mobile phones and wireless connections were the most frequently used technologies in education.

This result is explained by the fact that most of the students though are living within a highly technology driven era are yet to identify technologies that can be used in pedagogy. Most often students use the internet and related technologies for entertainment and social media with little or no idea how to use technology to facilitate the teaching/learning process. The results concur with [8] who found that secondary school Hindi teachers have sound knowledge regarding techno pedagogical skills that ensuring high educational outcomes and also for attaining high educational objectives in a meaningful way. Teachers on their part because of their greater experience and mindful of the difficulties they encountered before the advent of technology for example in preparing lessons, especially graphic lessons, access to resources, presentation of lessons, to name a few. Today the quick access to resources on the internet, projectors, and several platforms used in teaching and learning explain the positive perception of techno-pedagogy as a catalyst for better performance by teachers in HTTTC Kumba. Though teachers have a strong positive perception in HTTTC Kumba with a significant agreement towards a positive effect of elearning on teachers' performance, they do not apply elearning because the techno-pedagogic skills of students to support or sustain e-learning are questionable. The results also justify [9] who found out that techno-pedagogy enhances the student's motivation and engagement and enhances the quality of education.

\section{CONCLUSION AND RECOMMENDATIONS}

Judging from the results, it was concluded that there is a significant positive relationship between techno-pedagogical skills and teachers' performance in HTTTC Kumba. There is therefore a need for the techno-pedagogical skills of teachers to be improved to equip them to face the challenges of the classroom. Moreover, from a general observation of the trends of the results, one would see that techno-pedagogy is not really a strange concept in HTTTC Kumba among teachers and this can partly be credited for the fact that the College is a technical teacher training college dominated mainly by teachers of industrial and tertiary technologies. Though not fully practiced from observing the results, Elearning is well-known in HTTTC Kumba with much of it practiced in the classroom than in online. It also shows that techno-pedagogical skills affect different aspects of a teachers' daily performance and determines the outcome of the teaching job hence techno-pedagogy has a significant positive relationship with teachers' performance. Therefore, the development of techno-pedagogical skills is a key ingredient in improving teachers' performance in HTTTC Kumba.

Based on the results of the findings and the conclusions drawn from this study, some recommendations have been made to different stakeholders who stand to benefit from the results of this study.

The recommendation to the administration of HTTTC Kumba is that they should institute a general course called computer applications in education. This course should be compulsory to all the students of HTTTC Kumba. A Technical Teachers' Training College this will; set a good example and pave the way for future generations of teachers who will not only have a positive perception about technology but appropriately apply it in the teaching /learning process. Paraphrasing from the policy of the Faculty of Education in the University of Lethbridge (Alberta, Canada), each student entering the Faculty is required to take EDUC3508-Communications Technology and Education during Professional Semester I (PSI). The primary focus of the course is to provide experiences for the students that will help them effectively infuse technology into their future classrooms [4].

Educational administrators on their part should ensure adequate provision of the necessary resources and materials for the development as well as the application of technopedagogical skills in their establishments. Educational administrators can also identify resource persons within their educational institutions so that he /she can assist other teachers in the acquisition of techno-pedagogical skills.

Mindful of the significant positive relationship between techno-pedagogical skills and teachers' performance the researcher recommends not only the acquisition of these techno-pedagogical skills but more importantly a regular update of these skills by teachers. Teachers should regularly update their skills and sort ways of various ways of using these skills in the teaching/learning process.

The researchers recommend that all should acquire technopedagogical skill as a necessary tool to fosters the students for further development, attainment of learning outcomes and maintain the context of designing classroom-based resources through the use of ICT by the teachers.

Mindful of the significant positive relationship between technology and teachers' performance, the researcher recommends that the government should organise in-service programs for teachers on the development of technopedagogical skills. The government should also make provision for adequate resources like internet and materials especially projectors aönd computers for schools so as to facilitate the development of techno-pedagogical skills.

A follow up study to this study could be: The Development of Techno-Pedagogical Skills and the Performance of Students in HTTTC Kumba. 


\section{REFERENCES}

[1] Ackoff, R. L. (1953). The Design of Social Research. University of Chicago Press.

[2] Ames, C. W. (2016). Teacher Perceptions of Factors Influencing Technology Integration in K-12 Schools. Logan, Utah: Utah State University.

[3] Amin, M.E. (2005). Social Science Research: Conception, Methodology and Analysis. Makerere University Press, Kampala.

[4] Beaudin, L., \& Hadden, C. (2004). Developing technopedagogical skills in preservice teachers. World Conference on E-Learning in Corporate, Government, Healthcare, and Higher Education 2004 (pp. 492-498). Norfolk, VA: Association for the Advancement of Computing in Education.

[5] Etikan, I. (2015). Comparison of Convenience Sampling and Purposive. American Journal of Theoretical and Applied Statistics, $5(1), 1-4$.

[6] Hanane, L. and Djilali, B (2015). ICT and the Development of Techno-Pedagogical Skills among the Algerian University Teachers. Journal of Educational and Social Research, 5(1), 129.

[7] Harris, J. L., Mohammed, A.-B., \& Al-Bataineh, A. (2016). One to One Technology and its Effect on Student Academic Achievement and Motivation. Contemporary Educational Technology, 7(4), 368381.

[8] Kumar, P. S. (2018). A Study of Techno - Pedagogical skills of Secondary school Hindi teachers working in Kerala. International Journal of Advance Research and Innovative Ideas in Education, 4(1), 909-913.

[9] Mishra, C. B., \& Badugu, D. (2012). Relationship between Technology and Education: A Study in Indian Context. Journal of Entrepreneurship, Management and Innovation, 1-20.

[10] Şimşek, S., \& Arat, T. (2015). Communication tools used in teaching and their effects: an empirical study on the T.C. Selcuk University samples. Procedia Social and Behavioural Sciences, 174(1), $2639-$ 2646 . 